\title{
Application Of Dietary Approaches To Stop Hypertension (Dash) Diet: An Effort To Lower Blood Pressure In Individuals With Hypertension
}

\author{
Susanti Susanti ${ }^{1 *}$, Nata Ratnawati ${ }^{2}$, Lina Andriani ${ }^{3}$, Difran Nobel Bistara ${ }^{4}$ \\ ${ }^{1}$ Department of Nursing, Adi Husada College of Health Surabaya, 60141, Surabaya, East Java, Indonesia \\ ${ }^{2}$ Department of Nursing, Adi Husada College of Health Surabaya, 60141, Surabaya, East Java, Indonesia \\ ${ }^{3}$ Department of Nursing, Adi Husada College of Health Surabaya, 60141, Surabaya, East Java, Indonesia \\ ${ }^{4}$ Department of Nursing, Faculty of Nursing and Midwifery, Universitas Nahdlatul Ulama Surabaya, 60237 Surabaya, \\ East Java, Indonesia \\ *E-mail: susanti1303@gmail.com
}

\begin{tabular}{ll}
\hline Article submitted & : July, 12.2021 \\
Article Reviewed & $:$ December,2.2021 \\
Article Accepted & $:$ December,10.2021 \\
\hline
\end{tabular}

Article Accepted : December, 10.2021

Abstract

Diet DASH (Dietary Approaches To Stop Hypertension) is one method to lower blood pressure in individuals with hypertension. In addition, dietary factors (dietary compliance) are essential to consider. Individuals with hypertension should adhere to the DASH diet to prevent further complications. The implementation method in the community service program was providing health education on DASH diet application through lectures and questions and answers. The participants were 10 individuals with hypertension at Brigjen Katamso RT 23 RW 05 Kedung Rejo Village, Waru District, Sidoarjo Regency. Before health education on the DASH diet, most participants (60\%) had stage 1 hypertension. Meanwhile, most participants $(50 \%)$ were categorized in pre-hypertension after health education. The Wilcoxon SignedRank Test test resulted in $p=0.003$. Thus, there was an effect of health education on the DASH diet on blood pressure. In addition, before health education on the DASH diet, most respondents $(50 \%)$ had a food consumption pattern that triggers hypertension. Meanwhile, most respondents (90\%) had a good food consumption pattern after the health education. Thus, there was a change in food consumption patterns in participants. Health education on the DASH diet increased knowledge in individuals with hypertension. Increased knowledge encouraged participants to adjust their eating patterns as recommended in the DASH diet guide book. In conclusion, health education on the DASH diet can lower blood pressure in individuals with hypertension. Further community service activity should increase the number of participants and be more routine in its implementation to be helpful for the wider community.

Keywords: DASH diet; Blood pressure; Hypertension

Abstrak

Diet DASH (Dietary Approaches To Stop Hypertension) merupakan salah satu metode untuk menurunkan tekanan darah pada individu dengan hipertensi. Selain itu, faktor diet (kepatuhan diet) sangat penting untuk dipertimbangkan. Individu dengan hipertensi harus mematuhi diet DASH untuk mencegah komplikasi lebih lanjut. Metode pelaksanaan dalam program pengabdian masyarakat ini adalah dengan memberikan pendidikan kesehatan tentang penerapan diet DASH melalui ceramah dan tanya jawab. Partisipan adalah 10 orang penderita hipertensi di Brigjen Katamso RT 23 RW 05 Desa Kedung Rejo Kecamatan Waru Kabupaten Sidoarjo. Sebelum pendidikan kesehatan tentang diet DASH, sebagian besar peserta (60\%) memiliki hipertensi stadium 1. Sedangkan sebagian besar peserta (50\%) termasuk dalam kategori pra hipertensi setelah pendidikan kesehatan. Uji Wilcoxon Signed-Rank Test menghasilkan $p=0,003$. Dengan demikian, ada pengaruh pendidikan kesehatan tentang diet DASH terhadap tekanan darah. Selain itu, sebelum pendidikan kesehatan tentang diet DASH, sebagian besar responden (50\%) memiliki pola konsumsi makanan yang memicu hipertensi. Sedangkan sebagian besar responden (90\%) memiliki pola konsumsi makanan yang baik setelah diberikan pendidikan kesehatan. Sehingga terjadi perubahan pola konsumsi makanan pada peserta. Pendidikan kesehatan tentang diet DASH meningkatkan pengetahuan pada individu dengan hipertensi. Peningkatan pengetahuan mendorong peserta untuk menyesuaikan pola makan mereka seperti yang direkomendasikan dalam buku panduan diet DASH. Kesimpulannya, pendidikan kesehatan

300

Application Of Dietary Approaches To Stop

Hypertension (Dash) Diet: An Effort To Lower Blood

Pressure In Individuals With Hypertension

Susanti Susanti'Nata Ratnawati, Lina Andriani, Difran

Nobel Bistara 
tentang diet DASH dapat menurunkan tekanan darah pada individu dengan hipertensi. Selanjutnya kegiatan pengabdian kepada masyarakat hendaknya memperbanyak jumlah peserta dan lebih rutin dalam pelaksanaannya agar dapat bermanfaat bagi masyarakat luas.

\section{Kata kunci: diet DASH; Tekanan darah; Hipertensi}

\section{INTRODUCTION}

Hypertension still becomes a health problem in developed and developing countries (Kresnawan, 2011). It is a degenerative disease with a high morbidity and mortality level. High blood pressure is a strong risk factor for kidney disease and cardiovascular diseases such as stroke and ischemic heart disease (Kumala, 2014). Hypertension occupied the category of 10 leading causes of death in Indonesia, with a death rate of 42 thousand. According to Riskesdas 2013, hypertension prevalence in Indonesia was relatively high, namely 25.8\% (Health Research and Development Agency, 2013).

Hypertension or high blood pressure disease is a disorder in the blood vessels, resulting in the blocking supply of oxygen and nutrients to the body tissues (Dewifianita, 2017). Age, race, and family history are risk factors for hypertension that cannot be controlled. Meanwhile, risk factors for hypertension that can be controlled are excess body weight, lack of physical activity, smoking, excess sodium intake, lack of potassium, calcium, and magnesium intake, alcohol consumption, and stress (Kresnawan, 2011).

All people can suffer from hypertension from the lower, middle, and upper classes. Based on the cause, hypertension is divided into primary hypertension - hypertension with unknown causes - and secondary hypertension - hypertension with a known cause. The cause of hypertension is often not yet known. More than $90 \%$ of individuals with hypertension are classified as essential hypertension, while $10 \%$ is secondary hypertension. Primary hypertension usually occurs at the age of 30-50 years. It is due to lifestyle changes, consuming foods containing fat, cholesterol, smoking, and stress. Previous research showed that a lack of education caused dietary non-compliance in individuals with hypertension. They did not understand the negative impact of non-compliance with diet. Another cause was a low economic level correlated with food needs (Susanti, 2019).

One of the ways to manage hypertension is non-pharmacological treatment, including controlling diet, reducing salt intake, increasing potassium and magnesium consumption, and physical activity. Diet compliance is one of the factors that can prevent complications in hypertensive patients. The American Dietetic Association (ADA) states that diet can lower blood pressure and lower the risk of heart disease and stroke. One way to regulate hypertension is to use the Dietary Approaches to Stop Hypertension (DASH) diet (Nurmayanti \& Kaswari, 2020). The low salt diet recommended by doctors follows the principles of the DASH diet. The DASH diet is a diet therapy recommended by the American Heart Association (AHA). A study in the United States conducted by Scott L. Hummel and colleagues in 2012 showed that mean blood pressure before diet therapy was $155 / 79 \mathrm{mmHg}$ decreased to $138 / 72 \mathrm{mmHg}$ after diet therapy (Triwibowo et al., 2016).

The DASH diet consists of eating vegetables, fruits, and whole grains. In addition, it limits foods that are high in saturated fat, sugary drinks, and sweets. Patients must consume foods low in saturated fat and sodium and rich in potassium, calcium, magnesium, fiber, and protein (Ismalia \& Zuraida, 2016). Health education of DASH diet is an effort to control hypertension in middle-aged adults to prevent hypertension and improve health status and quality of life. 


\section{SITUATION ANALYSIS}

\section{General Description}

This community service activity was conducted at Brigadier General Katamso 2 RT 23 RW 05, Kedung Rejo Village, Waru District, Sidoarjo Regency. Before the covid-19 pandemic, there were elderly integrated health post activities, but these activities did not run during the pandemic. Integrated health post activities were checking blood pressure and administering vitamins. On January 13, 2021, we started meeting cadres before the community service activity. In addition, the assessment data included participants' knowledge in hypertension, physical activity, and hypertension diet.

\section{Problem}

The target community often experienced hypertension, high cholesterol, and gout. Still, many of the residents in Kedung Rejo Village did not adhere to the diet for hypertension, so it was difficult to regulate blood pressure.

\section{Target Solution}

To overcome the above problem, the implementation of community service activity was health education on the DASH diet application to increase efforts to control hypertension.

\section{METHOD}

The implementation method in the community service program was providing health education on DASH diet application through lectures and questions and answers. In addition, initial activities were field surveys, counseling, and making a health education proposal. Then, the Authors did online and offline health education on January 28, 2021. Online health education used a laptop with the Zoom application. Meanwhile, offline health education was carried out in one of the residents' houses. The participants were individuals with hypertension in Kedung Rejo Village, Waru District, Sidoarjo Regency. There were ten participants, ages 36-60 years old. The health education materials were hypertension definition, hypertension classification, the DASH diet, foods consumed during the diet, the benefits of dieting, dieting tips, food, and drink menus. In addition, We gave the DASH diet guidebook to improve their comprehending.

\section{RESULTS AND DISCUSSION}

The blood pressure examination before and after health education on the DASH diet was shown in Table 1. In addition, the classification of hypertension was based on the ACC/AHA2017 Guidelines.

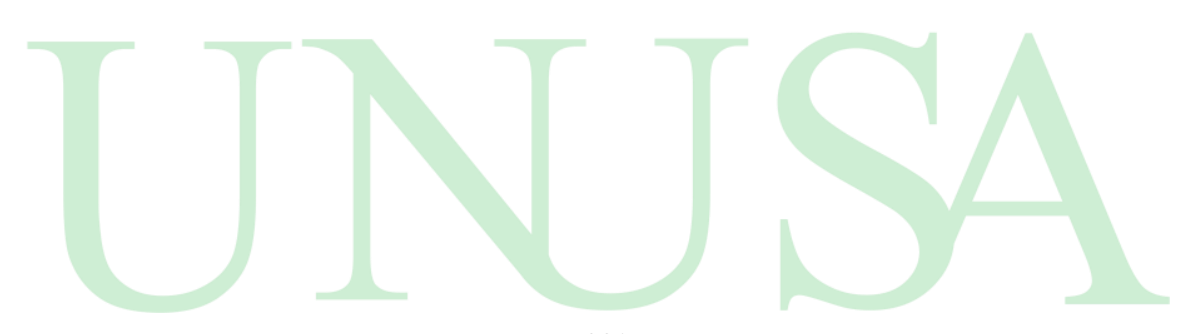

302

Application Of Dietary Approaches To Stop Hypertension (Dash) Diet: An Effort To Lower Blood Pressure In Individuals With Hypertension 
Table 1. Blood pressure before and after health education on the DASH diet

\begin{tabular}{|c|c|c|c|c|c|}
\hline \multirow{2}{*}{ Num. } & \multirow{2}{*}{$\begin{array}{l}\text { Classification of } \\
\text { Blood Pressure }\end{array}$} & \multicolumn{2}{|c|}{ Pre-test } & \multicolumn{2}{|c|}{ Post-test } \\
\hline & & Frequency & Percentage & Frequency & Percentage \\
\hline 1. & Normal & 0 & $0 \%$ & 3 & $30 \%$ \\
\hline 2. & $\begin{array}{l}\text { Pre- } \\
\text { hypersention/Elevate } \\
\text { d }\end{array}$ & 3 & $30 \%$ & 5 & $50 \%$ \\
\hline 3. & Stage 1 hypertension & 6 & $60 \%$ & 2 & $20 \%$ \\
\hline 4. & Stage 2 hypertension & 1 & $10 \%$ & 0 & $0 \%$ \\
\hline 5. & Hypertensive crisis & 0 & $0 \%$ & 0 & $0 \%$ \\
\hline & Total & 10 & $100 \%$ & 10 & $100 \%$ \\
\hline
\end{tabular}

Before health education on the DASH diet, most participants (60\%) had stage 1 hypertension. Meanwhile, most participants $(50 \%)$ were categorized in pre-hypertension after health education. The Wilcoxon SignedRank Test test resulted in $p=0.003$. Thus, there was an effect of health education on the DASH diet on blood pressure.

Before health education on the DASH diet, most respondents (50\%) had a food consumption pattern that triggers hypertension. Meanwhile, most respondents (90\%) had a good food consumption pattern after the health education. Thus, there was a change in food consumption patterns in participants. Health education on the DASH diet increased knowledge in individuals with hypertension. Increased knowledge encouraged participants to adjust their eating patterns as recommended in the DASH diet guide book.

The DASH diet approach requires people to abstain from salt. In addition, it more emphasizes foods that can help lower blood pressure as alternative medicine. These foods consist of vegetables and fruits containing functional compounds to lower blood pressure. For example, potatoes, sweet potatoes, green vegetables, and beans contain high potassium elements. Potassium will encourage the disposal of sodium elements out of the body to regulate blood pressure (Irmaviani, 2019).

According to Notoatmodjo (2012), health education will increase knowledge. Then increased knowledge can form positive behavior. Individuals will change their behavior when they know the benefits of the behavior. In addition, the result of this paper is in line with a study by Kurniawati \& Widiatie (2016) that reported a significant effect of providing health education on dietary compliance in patients with hypertension.

\section{CONCLUSION AND SUGGESTIONS}

In conclusion, health education on the DASH diet can lower blood pressure in individuals with hypertension in Kedung Rejo Village, Waru District, Sidoarjo Regency. Hopefully, the following community service activity can be carried out by students and developed according to technological advances. The next community service activity also could increase the number of participants and be more 
routine in its implementation to be helpful for the wider community. As a result, individuals with hypertension can achieve a better level of public health. In addition, a further implementation should consider mental, physical readiness and good cooperation between personnel or teams in groups.

\section{ACKNOWLEDGMENTS}

Thank you to all respondents and individuals for assistance throughout our study and help in the manuscript preparation. We also would like to express our great appreciation to Adi Husada College of Health Sciences and Nahdlaltul Ulama University Surabaya for their support. May God bestow mercy and comfort on us all.

\section{REFERENCES}

Dewifianita, R. (2017). Pengaruh Pemberian Konseling Diet Dash (Dietary Approach To Stop Hypertension) Terhadap Perubahan Tekanan Darah Pada Penderita Hipertensi Peserta Prolanis Di Puskesmas Sentolo.

Irmaviani, S. (2019). The Effectiveness of Media Booklet About DASH (Dietary Approches To Stop Hypertension) Information on Hypertension Patients (Age 35-44 Years) In Muara Jejak Ketapang Village.

Ismalia, N., \& Zuraida, R. (2016). Efek Tomat (Lycopersion esculentum Mill) dalam Menurunkan Tekanan Darah Tinggi. MAJORITY, 5(4), 107-111.

Kresnawan, T. (2011). Asuhan Gizi Pada Hipertensi. Gizi Indonesia, 34(2), 143-147.

Kumala, M. (2014). Peran Diet Dalam Pencegahan Dan Terapi Hipertensi. DAMIANUS Journal of Medicine, $13(1), 50-61$.

Kurniawati, \& Widiatie, W. (2016). Pengaruh Pendidikan Kesehatan Terhadap Kepatuhan Diet Pada Penderita Hipertensi. The Indonesian Journal Of Health Science, 7(1).

Notoatmodjo, S. (2012). Promosi Kesehatan dan Perilaku Kesehatan. RINEKA CIPTA.

Nurmayanti, H., \& Kaswari, S. R. T. (2020). Efektivitas Pemberian Konseling Tentang Diet Dash terhadap Asupan Natrium, Kalium, Kalsium, Magnesium, Aktivitas Fisik, dan Tekanan Darah Pasien Hipertensi. JURNAL NUTRITURE, 1(1), 63-75.

Susanti S., (2019). Diet Compliance with Complications in Patients. Adi Husada Nursing Journal, 5(1), 3036.

Triwibowo, H., Frilasari, H., \& Dewi, I. R. (2016). Hubungan Kepatuhan Diet Hipertensi Dengan Tekanan Darah Pada Pasien Hipertensi Di Poli Penyakit Dalam Rsud Prof.Dr.Soekandar Mojokerto. Jurnal Keperawatan, 5(1).

Application Of Dietary Approaches To Stop Hypertension (Dash) Diet: An Effort To Lower Blood Pressure In Individuals With Hypertension 